\title{
Detecting delirium in elderly medical emergency patients: validation and subsequent modification of the German nursing delirium screening scale-comment
}

\author{
Florian F. Grossmann ${ }^{1,2}$ (D) Wolfgang Hasemann ${ }^{3}\left[\right.$ C $\cdot$ Christian H. Nickel ${ }^{1}(\mathbb{D}$
}

Received: 17 December 2018 / Accepted: 21 December 2018 / Published online: 9 January 2019

c) Società Italiana di Medicina Interna (SIMI) 2019

\section{Dear Editor,}

We have read with interest the paper of Brich et al. [1] published online in this journal on 27 November. We support the authors' efforts to improve delirium detection in the ED setting. Their study showed moderate sensitivity and good specificity of the Nu-Desc delirium observation tool.

The authors' conclusion, however, merits discussion. First, the $\mathrm{Nu}$-Desc tool does not take inattention into account, which is - according to the Diagnostic and Statistical Manual of Mental Disorders (DSM) - the main feature of delirium. Therefore, criterion validity might be questioned [2].

Further, we disagree with the conclusion that a sensitivity of $77.8 \%$, as found in the modified Nu-Desc, is sufficient. Other validated screening tools, incorporating a formal test for inattention, showed better performance in ED patients [3-5]. The months of the year backwards test, for example, is frequently used in such tools. The screening step of the mCAM-ED [5], which is the months of the year backwards test, had a sensitivity of $95 \%$ and a negative likelihood ratio of 0.06 [5]. In the majority of patients (80\%), the months of the year backwards test can be applied in less than $30 \mathrm{~s}$. Of note, two-step tools such as DTS/bCAM [3] and mCAM-ED [5] will stop evaluation after a negative screening, which is ideal in the ED setting.

Florian F. Grossmann

florian.grossmann@usb.ch

1 Emergency Department, University Hospital Basel, Petersgraben 2, $4031 \mathrm{Basel}$, Switzerland

2 Division of Nursing, Department of Medicine, University Hospital Basel, Hebelstrasse 2, 4031 Basel, Switzerland

3 Department of Nursing and Allied Health Professions, University Hospital Basel, Hebelstrasse 2, 4031 Basel, Switzerland

\section{Compliance with ethical standards}

Conflict of interest The author(s) declare that they have no competing interests.

Statements on human and animal rights This article does not contain any studies with human participants or animals performed by any of the authors.

Informed consent None.

\section{References}

1. Brich J, Baten V, Wussmann J, Heupel-Reuter M, Perlov E, Kloppel S, Busch HJ (2018) Detecting delirium in elderly medical emergency patients: validation and subsequent modification of the German Nursing Delirium Screening Scale. Intern Emerg Med. https://doi.org/10.1007/s11739-018-1989-5

2. Savaskan E, Hasemann W (eds) (2017) Leitlinie Delir. Empfehlungen zur Prävention, Diagnostik und Therapie des Delirs im Alter, 1st edn. Hogrefe, Bern

3. Han JH, Wilson A, Vasilevskis EE, Shintani A, Schnelle JF, Dittus RS, Graves AJ, Storrow AB, Shuster J, Ely EW (2013) Diagnosing delirium in older emergency department patients: validity and reliability of the delirium triage screen and the brief confusion assessment method. Ann Emerg Med 62(5):457-465. https://doi. org/10.1016/j.annemergmed.2013.05.003

4. O'Sullivan D, Brady N, Manning E, O'Shea E, O'Grady S, O'Regan N, Timmons S (2018) Validation of the 6-Item Cognitive Impairment Test and the 4AT test for combined delirium and dementia screening in older emergency department attendees. Age Ageing 47(1):61-68. https://doi.org/10.1093/ageing/afx149

5. Hasemann W, Grossmann FF, Stadler R, Bingisser R, Breil D, Hafner M, Kressig RW, Nickel CH (2018) Screening and detection of delirium in older ED patients: performance of the modified confusion assessment method for the emergency department (mCAM-ED). A two-step tool. Intern Emerg Med 13(6):915-922. https://doi.org/10.1007/s11739-017-1781-y

Publisher's Note Springer Nature remains neutral with regard to jurisdictional claims in published maps and institutional affiliations. 